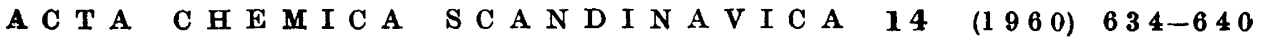

\title{
Low Temperature Heat Capacities and Thermodynamic Properties of the $\mathrm{Ni}_{1-x} \mathrm{Se}$-Phase
}

\author{
FREDRIK GRøNVOLD and TORKILD THURMAN - MOE \\ Kjemisk Institutt A, Universitetet $i$ Oslo, Blindern, Norway \\ and \\ EDGAR F. WESTRUM, JR. and NORMAN E. LEVITIN \\ Department of Chemistry, University of Michigan, Ann Arbor, Michigan, U.S.A.
}

\begin{abstract}
Heat capacities of three nickel selenides with compositions $\mathrm{Ni}_{0.98} \mathrm{Se}$, $\mathrm{Ni}_{0.875} \mathrm{Se}$ and $\mathrm{Ni}_{0.80} \mathrm{Se}$, representing the $\mathrm{Ni}_{1-x} \mathrm{Se}$-phase with $\mathrm{NiAs}$-like structure and cation vacancies, were measured in the range 5 to $350^{\circ} \mathrm{K}$. No transitions or other heat-capacity anomalies were observed, except for slight upward trends in the heat-capacity values for $\mathrm{Ni}_{\mathbf{0 . 8 7 5}} \mathrm{Se}$ and $\mathrm{Ni}_{0.80} \mathrm{Se}$ compared to those for $\mathrm{Ni}_{0.95} \mathrm{Se}$ above $250^{\circ} \mathrm{K}$, which might possibly indicate the beginning of transitions. Values for the enthalpy function and entropy were calculated and tabulated for several tem. peratures. At $298.15^{\circ} \mathrm{K}$ the entropies are 8.754 eu for $\mathrm{Ni}_{0.4872} \mathrm{Se}_{0.5128}(i$.e. $\mathrm{Ni}_{0.95} \mathrm{Se}$ ), 8.608 eu for $\mathrm{Ni}_{0.4687} \mathrm{Se}_{0.5333}\left(i . e . \mathrm{Ni}_{0.875} \mathrm{Se}\right.$ or $\mathrm{Ni}_{7} \mathrm{Se}_{8}$ ) and 8.506 ou for $\mathrm{Ni}_{0.4444} \mathrm{Se}_{0.6586}\left(i . e . \mathrm{Ni}_{0.80} \mathrm{Se}\right.$ or $\left.\mathrm{Ni}_{4} \mathrm{Se}_{3}\right)$.
\end{abstract}

$\mathbf{T}$ $\mathrm{Ni}_{1-x} \mathrm{Se}$-phase offers interesting possibilities for studying an orderdisorder process as a function of composition and of temperature from a combined structural and thermodynamic point of view. It was shown by Alsén ${ }^{1}$ that NiSe has a hexagonal structure of the NiAs-type in which each nickel atom is surrounded by six selenium atoms at the corners of a slightly irregular octahedron, or trigonal antiprism. These antiprisms are stacked on top of each other in the $c$-direction so that the nickel atoms form endless chains in this direction.

More recent work has shown ${ }^{2}$ that the $\mathrm{Ni}_{1-x} \mathrm{Se}$-phase has a composition varying between $\mathrm{Ni}_{0.98} \mathrm{Se}$ and $\mathrm{Ni}_{0.77} \mathrm{Se}$ and that the stoichiometric 1:1 ratio is not included, at least not in the case of samples heat-treated at 550 and $400^{\circ} \mathrm{C}$ when examined by X-ray diffraction at room temperature. The structure is hexagonal only in the nickel-rich range, and additional, weak reflections are observed when $1-x$ is less than 0.91 , indicating the presence of superstructure. For a sample with composition $\mathrm{Ni}_{0.87} \mathrm{Se}$ the superstructure was found to be orthorhombic with $A=a \sqrt{3}, B=3 a$ and $C=3 c$, where $a$ and $c$ are the dimen- 
sions of the hexagonal unit. With further increase in the number of vacant $\mathrm{Ni}$-positions below $\mathrm{Ni}_{\mathbf{0 . 8 3}} \mathrm{Se}$, the basic structure changes from hexagonal to monoclinic, and at the composition $\mathrm{Ni}_{0.80}$ Se the size of the unit cell is $A^{\prime}=a \sqrt{3}$, $B^{\prime}=a, C^{\prime}=2 c$ and $\beta=90.52^{\circ}$.

A determination of the atomic arrangement in $\mathrm{Ni}_{0.80} \mathrm{Se}$ has ascertained ${ }^{3}$ that there is a considerable degree of order among the vacancies after the $20 \%$ missing nickel atoms. These vacancies are distributed in an ordered way in every other layer of metal atoms normal to the $c$-axis, while apparently almost no vacancies exist in the rest of the layers. Slight movements of nickel and selenium atoms in the vicinity of the vacancies are observed, but in general, the structure is little affected. The contraction in volume by the $5.32 \%$ decrease in mass per unit cell is $5.26 \%$.

The $\mathrm{Ni}_{1-x}$ Se-phase shows metallic behavior, with a weak, almost temperature-independent paramagnetism. Thus its heat capacity behavior is expected to resemble that of the $\delta$-phase in the nickel-tellurium system ${ }^{4}$ which shows no magnetic transitions and rather small variations in heat capacity as a function of composition.

The nickel selenides are rather different from the iron selenides ${ }^{5}$ in that no clear-cut separation into two-phase regions occurs within the $\mathrm{Ni}_{1-x} \mathrm{Se}$-phase. Therefore, it was thought of interest to carry out heat-capacity measurements on the nickel selenides in order to ascertain if the apparent absence of exsolution into phases of slightly different compositions is caused by failure of the nickel selenides to reach equilibrium (in contrast to what seems to be the case for the iron selenides), or by too small an entropy increment between ordered and slightly disordered states to cause such separation.

This requires studying a thermodynamic cycle involving free energy measurements as well as enthalpy and entropy measurements. The enthalpy of formation of the $\mathrm{Ni}_{1-x} \mathrm{Se}$-phase has been determined ${ }^{6}$ at $775^{\circ} \mathrm{C}$, and hightemperature heat-capacity measurements are presently in progress to study entropy changes accompanying the order-disorder process.

In this paper are reported the results of low-temperature heat-capacity measurements carried out on three single-phase samples within the homogeneity range of the $\mathrm{Ni}_{1-x} \mathrm{Se}$-phase, having compositions $\mathrm{Ni}_{\mathbf{0} .95} \mathrm{Se}, \mathrm{Ni}_{\mathbf{0 . 8 7 5}} \mathrm{Se}$ and $\mathrm{Ni}_{0.80} \mathrm{Se}$.

\section{EXPERIMENTAL}

A. Preparation of the samples. The nickel selenides were prepared by fusion of highpurity nickel and selenium. "Nickel oxide, low in cobalt and iron" from the British Drug Houses Ltd. was reduced with dry, purified hydrogen gas at $500^{\circ} \mathrm{C}$ for $5 \mathrm{~h}$. The resulting, malleable nickel was broken into pieces and reduced again, this time at $1000^{\circ} \mathrm{C}$ for $4 \mathrm{~h}$. Spectrographic analysis showed the presence of the following impurities (in ppm): $\mathrm{Al}(100)$, $\mathrm{Ba}(1), \mathrm{Ca}(10), \mathrm{Co}(10), \mathrm{Cr}(1), \mathrm{Cu}(1), \mathrm{Fe}(10), \mathrm{Mg}(50), \mathrm{Mn}(1), \mathrm{Si}(50)$.

The high-purity selenium was a gift from Bolidens Gruvaktiebolag. According to their analysis it contained these impurities (in ppm): $\mathrm{Cl}(2), \mathrm{Fe}(0.8), \mathrm{K}(0.3)$, $\mathrm{Na}(0.4)$, nonvolatile matter (12). The following elements were not detected (the numbers indicate the sensitivity limit in $\mathrm{ppm}): \mathrm{Ag}(0.03), \mathrm{Al}(0.3), \mathrm{As}(1), \mathrm{Bi}(0.1), \mathrm{Ca}(1), \mathrm{Cr}(0.3), \mathrm{Cu}(0.1), \mathrm{Hg}(0.5)$, $\mathrm{Mg}(0.3), \operatorname{Mn}(0.1), \mathrm{Ni}(0.3), \mathrm{Pb}(0.3), \mathrm{S}(5), \mathrm{Si}(1), \operatorname{Sn}(0.3), \mathrm{Te}(1), \mathrm{Zn}(1)$.

Accurately-weighed quantities of nickel and selenium corresponding to the compositions $\mathrm{Ni}_{0.95} \mathrm{Se}, \mathrm{Ni}_{0.875} \mathrm{Se}$ and $\mathrm{Ni}_{0.80} \mathrm{Se}$ were heated in evacuated and sealed vitreous silica tubes. The samples were fused for $2 \mathrm{~h}$ at 1050,1000 and $950^{\circ} \mathrm{C}$, respectively. They were 
then cooled, fragmented and annealed at $550^{\circ} \mathrm{C}$ for seven days and cooled over a period of two more days. X-Ray powder photographs of the samples were identical to those obtained earliers.

B. Cryostat and calorimeter. The Mark I cryostat and technique employed in lowtemperature adiabatic calorimetry will be described elsewhere? ${ }^{7}$. Two different calorimeters were used, W-7 with a capacity of $40 \mathrm{~cm}^{3}$ was used for the $\mathrm{Ni}_{0.95} \mathrm{Se}$ and $\mathrm{Ni}_{0.875} \mathrm{Se}$ samples, while calorimeter W-17 with a capacity of $60 \mathrm{~cm}^{3}$ was used for the $\mathrm{Ni}_{0.80} \mathrm{Se}$ sample. Both calorimeters are gold-plated and have four and two vanes, respectively. Separate series of measurements were carried out to determine the heat capacities of the empty calorimeters, using the same thermometer and heater and exactly the same amount of indium-tin solder for sealing the calorimeter and Apiezon-T grease for thermal contact with the thermometer and heater. The heat capacity of the empty calorimeter W-7 represented from 17 to $25 \%$ of the total heat capacity, and that of calorimeter W-17 from 16 to $21 \%$.

Temperatures were measured with a capsule-type platinum resistance thermometer (laboratory designation A-3) within an axial well in the calorimeter. The thermometer was calibrated by the National Bureau of Standards, and the temperatures were judged to correspond with the thermodynamic temperature scale within $0.1^{\circ} \mathrm{K}$ from 5 to $10^{\circ} \mathrm{K}$, $0.03^{\circ} \mathrm{K}$ from 10 to $90^{\circ} \mathrm{K}$ and $0.04^{\circ} \mathrm{K}$ from 90 to $350^{\circ} \mathrm{K}$. Precision is considerably better, and the temperature increments are probably accurate to $0.001^{\circ} \mathrm{K}$ after corrections for quasi-adiabatic drift.

The thermometer resistance and power input were measured with a calibrated White double-potentiometer, calibrated resistances and a calibrated standard cell. An electric timer, operated by a calibrated tuning fork and amplifier, was automatically started at the beginning of the heating period and stopped at the end.

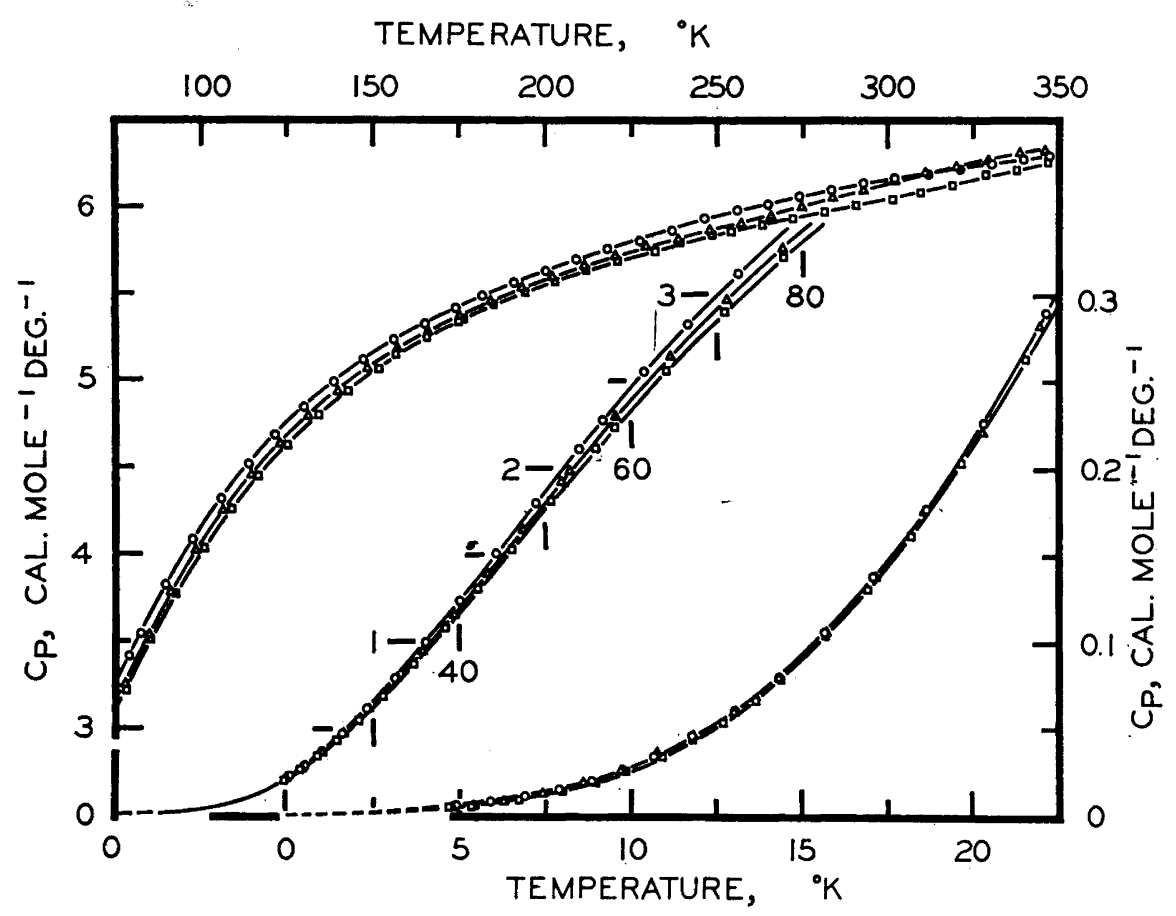

Fig. 1. Heat capacities of nickel selenides on a gram formula weight basis: $O$ represents $\mathrm{Ni}_{0.4872} \mathrm{Se}_{0.6128}, \Delta$ represents $\mathrm{Ni}_{0.4667} \mathrm{Se}_{0.5333}$ and $\square$ represents $\mathrm{Ni}_{0.4441} \mathrm{Se}_{0.5568}$.

Acta Chem. Scand. 14 (1960) No. 3 
Table 1. Heat capacities of nickel selenides, cal ${ }^{\circ} \mathrm{K}^{-1}$ "mole"-1.

\begin{tabular}{|c|c|c|c|c|c|}
\hline$T,{ }^{\circ} \mathrm{K}$ & $C_{p}$ & $T,{ }^{\circ} \mathrm{K}$ & $C_{p}$ & $T,{ }^{\circ} \mathrm{K}$ & $C_{p}$ \\
\hline \multicolumn{6}{|c|}{$\mathrm{Ni}_{0.950} \mathrm{Se}$} \\
\hline \multicolumn{6}{|c|}{ (formula weight $\mathrm{Ni}_{0.4872} \mathrm{Se}_{0.5128}=69.09 \mathrm{~g}$ ) } \\
\hline \multirow{2}{*}{\multicolumn{2}{|c|}{ Series I }} & 20.27 & 0.2266 & 156.18 & 5.234 \\
\hline & & 22.09 & 0.2900 & 165.03 & 5.326 \\
\hline 56.71 & 2.270 & 24.11 & 0.3680 & 174.05 & 5.418 \\
\hline 61.59 & 2.551 & 26.48 & 0.4719 & 183.04 & 5.498 \\
\hline 66.77 & 2.821 & 29.29 & 0.6095 & 182.04 & 5.491 \\
\hline 72.47 & 3.114 & 32.58 & 0.7884 & 191.02 & 5.565 \\
\hline 78.89 & 3.409 & 36.14 & 0.9964 & 200.06 & 5.628 \\
\hline \multirow{3}{*}{\multicolumn{2}{|c|}{ Series II }} & 40.01 & 1.233 & 209.17 & 5.696 \\
\hline & & 44.32 & 1.503 & 218.35 & 5.756 \\
\hline & & 48.96 & 1.796 & 227.56 & 5.803 \\
\hline 4.91 & 0.006 & 53.97 & 2.108 & 237.01 & 5.865 \\
\hline 5.88 & 0.008 & \multirow{3}{*}{\multicolumn{2}{|c|}{ Series III }} & 246.47 & 5.933 \\
\hline 6.88 & 0.011 & & & 255.78 & 5.978 \\
\hline 7.89 & 0.015 & & & 264.93 & 6.013 \\
\hline 8.84 & 0.020 & 82.09 & 3.541 & 274.18 & 6.059 \\
\hline 9.76 & 0.027 & 89.30 & 3.824 & 283.52 & 6.097 \\
\hline 10.66 & 0.034 & 97.37 & 4.083 & 292.84 & 6.139 \\
\hline 11.78 & 0.046 & 105.89 & 4.318 & 302.13 & 6.164 \\
\hline 13.03 & 0.0610 & 113.91 & 4.517 & 311.55 & 6.190 \\
\hline 14.32 & 0.0809 & 121.59 & 4.686 & 321.06 & 6.218 \\
\hline 15.65 & 0.1050 & 129.88 & 4.846 & 330.48 & 6.247 \\
\hline 17.08 & 0.1378 & 138.58 & 4.993 & 339.86 & 6.278 \\
\hline 18.62 & 0.1767 & 147.33 & 5.119 & 347.33 & 6.296 \\
\hline \multicolumn{6}{|c|}{$\mathrm{Ni}_{0.875} \mathrm{Se}$} \\
\hline \multicolumn{6}{|c|}{ (formula weight $\mathrm{Ni}_{\mathbf{0 . 4 6 6 7}} \mathrm{S}_{0.5333}=69.51 \mathrm{~g}$ ) } \\
\hline 4.82 & 0.005 & 39.40 & 1.155 & 175.18 & 5.371 \\
\hline 5.39 & 0.007 & 43.27 & 1.394 & 184.20 & 5.452 \\
\hline 6.28 & 0.008 & 47.41 & 1.645 & 193.28 & 5.530 \\
\hline 7.42 & 0.013 & 51.88 & 1.917 & 202.40 & 5.598 \\
\hline 8.60 & 0.019 & 52.95 & 1.981 & 211.59 & 5.659 \\
\hline 9.70 & 0.026 & 58.25 & 2.295 & 220.65 & 5.716 \\
\hline 10.76 & 0.036 & 64.59 & 2.642 & 229.79 & 5.767 \\
\hline 11.84 & 0.047 & 71.20 & 2.966 & 239.01 & 5.813 \\
\hline 12.98 & 0.0604 & 77.54 & 3.255 & 248.11 & 5.863 \\
\hline 14.27 & 0.0797 & 84.02 & 3.535 & 257.09 & 5.903 \\
\hline 15.66 & 0.1056 & 90.82 & 3.787 & 265.97 & 5.949 \\
\hline 17.11 & 0.1379 & 98.27 & 4.023 & 274.98 & 6.002 \\
\hline 18.57 & 0.1757 & 106.39 & 4.252 & 283.88 & 6.052 \\
\hline 20.13 & 0.2210 & 114.65 & 4.457 & 292.94 & 6.098 \\
\hline 21.94 & 0.2820 & 123.00 & 4.635 & 302.05 & 6.155 \\
\hline 24.12 & 0.3644 & 131.36 & 4.795 & 311.05 & 6.200 \\
\hline 26.66 & 0.4734 & 139.77 & 4.934 & 320.15 & 6.237 \\
\hline 29.47 & 0.6082 & 148.46 & 5.068 & 329.40 & 6.272 \\
\hline 32.51 & 0.7665 & 157.25 & 5.185 & 338.66 & 6.317 \\
\hline 35.80 & 0.9489 & 166.19 & 5.283 & 345.99 & 6.327 \\
\hline
\end{tabular}

Acta Chem. Scand. 14 (1960) No. 3 
Table 1 (continued).

\begin{tabular}{|c|c|c|c|c|c|}
\hline \multicolumn{6}{|c|}{$\mathrm{Ni}_{0.800} \mathrm{Se}$} \\
\hline \multicolumn{6}{|c|}{ (formula weight $\mathrm{Ni}_{0.4444} \mathrm{Se}_{0.5556}=69.96 \mathrm{~g}$ ) } \\
\hline \multicolumn{2}{|c|}{ Series I } & 337.72 & 6.214 & 25.77 & 0.4312 \\
\hline & & 346.76 & 6.256 & 28.30 & 0.5446 \\
\hline 156.88 & 5.150 & & & 31.10 & 0.6830 \\
\hline 165.84 & 5.250 & & & 34.58 & 0.8702 \\
\hline 174.93 & 5.339 & & & 38.33 & 1.080 \\
\hline 176.40 & 5.351 & 5.36 & 0.006 & 42.13 & 1.302 \\
\hline 185.38 & 5.434 & 4.68 & 0.005 & 46.18 & 1.530 \\
\hline 194.29 & 5.507 & 5.48 & 0.006 & 50.76 & 1.812 \\
\hline 203.10 & 5.569 & 6.73 & 0.009 & 55.95 & 2.112 \\
\hline 212.01 & 5.629 & 8.03 & 0.014 & 58.08 & 2.226 \\
\hline 221.09 & 5.688 & 8.97 & 0.020 & 64.04 & 2.553 \\
\hline 230.22 & 5.741 & 9.87 & 0.026 & 70.82 & 2.892 \\
\hline 239.42 & 5.791 & 10.87 & 0.034 & 77.82 & 3.212 \\
\hline 248.70 & 5.831 & 11.80 & 0.0439 & 84.76 & 3.510 \\
\hline 254.12 & 5.855 & 12.67 & 0.0538 & 92.43 & 3.778 \\
\hline 263.27 & 5.899 & 13.60 & 0.0669 & 100.64 & 4.035 \\
\hline 272.43 & 5.937 & 14.38 & 0.0790 & 108.85 & 4.261 \\
\hline 281.60 & 5.974 & 15.68 & 0.1042 & 116.87 & 4.455 \\
\hline 290.82 & 6.010 & 16.89 & 0.1303 & 125.13 & 4.631 \\
\hline 300.14 & 6.044 & 18.15 & 0.1615 & 134.31 & 4.803 \\
\hline 309.57 & 6.083 & 19.63 & 0.2030 & 142.84 & 4.940 \\
\hline 319.10 & 6.127 & 21.49 & 0.2630 & 151.64 & 5.066 \\
\hline 328.61 & 6.169 & 23.56 & 0.3399 & & \\
\hline
\end{tabular}

The calorimeter was loaded with sample and evacuated, and helium added at $5 \mathrm{~cm}$ $\mathrm{Hg}$ pressure at about $25^{\circ} \mathrm{C}$ to provide thermal contact between calorimeter and sample. It was then placed in the cryostat and cooled. The mass of sample used was $162.675 \mathrm{~g}$ $\mathrm{Ni}_{0.98} \mathrm{Se}, 171.863 \mathrm{~g} \mathrm{Ni}_{0.878} \mathrm{Se}$ and $172.998 \mathrm{~g} \mathrm{Ni} \mathrm{Ni}_{0.80} \mathrm{Se}$.

\section{RESULTS}

The heat-capacity determinations are listed in Table 1 in chronological order, and expressed in terms of the thermochemical calorie, defined as 4.1840 abs joules. The ice point is taken to be $273.15^{\circ} \mathrm{K}$ and the atomic weights of nickel and selenium as 58.71 and 78.96, respectively. The data are expressed in terms of one mole of mixture, "mole", equivalent to the gram formula weight of $\mathrm{Ni}_{y} \mathrm{Se}_{1-y}$, i.e., $69.09 \mathrm{~g} \mathrm{Ni}_{0.95} \mathrm{Se}, 69.51 \mathrm{~g} \mathrm{Ni}_{0.875} \mathrm{Se}$ and $69.96 \mathrm{~g} \mathrm{Ni}_{0.80} \mathrm{Se}$. An analytically-determined curvature correction for the finite temperature increments was applied to the observed values of $\Delta H / \Delta T$. The approximate temperature increments can usually be inferred from the adjacent mean temperature values in Table 1.

The heat capacity versus temperature curves are shown in Fig. 1. For $\mathrm{Ni}_{0.95} \mathrm{Se}$ it has the usual sigmoidal shape, with no anomalies or other irregular behavior up to $350^{\circ} \mathrm{K}$. For $\mathrm{Ni}_{0.875} \mathrm{Se}$ and $\mathrm{Ni}_{0.80} \mathrm{Se}$ a slight relative increase in the values compared to those of $\mathrm{Ni}_{0.95} \mathrm{Se}$ is observed above $250^{\circ} \mathrm{K}$. This might possibly indicate the beginning of transitions. 
Table 2. Thermodynamic properties of nickel selenides, cal ${ }^{\circ} \mathrm{K}^{-1}$ "mole"-1.

\begin{tabular}{|c|c|c|c|c|c|c|c|c|c|}
\hline & \multicolumn{3}{|c|}{$\mathrm{Ni}_{0.950} \mathrm{Se}$} & \multicolumn{3}{|c|}{$\mathrm{Ni}_{0.875} \mathrm{Se}$} & \multicolumn{3}{|c|}{$\mathrm{Ni}_{\mathbf{0 . 8 0}} \mathrm{Se}$} \\
\hline & \multicolumn{3}{|c|}{$\begin{array}{c}\text { (formula weight } \\
\left.\mathrm{Ni}_{0.4872} \mathrm{Se}_{0.5128}=69.09 \mathrm{~g}\right)\end{array}$} & \multicolumn{3}{|c|}{$\begin{array}{c}\text { (formula weight } \\
\left.\mathrm{Ni}_{0.4667} \mathrm{Se}_{0.5333}=69.51 \mathrm{~g}\right)\end{array}$} & \multicolumn{3}{|c|}{$\begin{aligned} \text { (formula weight } & \text { weigh } \\
\mathrm{Ni}_{0.4444} \mathrm{Se}_{0.5558} & =69.96 \mathrm{~g})\end{aligned}$} \\
\hline$T,{ }^{\circ} \mathrm{K}$ & $C_{p^{\circ}}$ & $S^{\circ}-S_{0}^{\circ}$ & $\frac{H^{\circ}-H_{0}^{\circ}}{T}$ & $C_{p}^{\circ}$ & $\mathrm{S}^{\circ}-S_{0}^{\circ}$ & $\frac{H^{\circ}-H_{0}^{\circ}}{T}$ & $C_{p}^{\circ}$ & $S^{\circ}-S_{0}^{\circ}$ & $\frac{H^{\circ}-H_{0}^{\circ}}{T}$ \\
\hline 10 & 0.028 & 0.0110 & 0.0080 & 0.029 & 0.0110 & 0.0080 & 0.027 & 0.0100 & 0.0073 \\
\hline 15 & 0.093 & 0.0330 & 0.0241 & 0.093 & 0.0331 & 0.0242 & 0.090 & 0.0311 & 0.0229 \\
\hline 20 & 0.218 & 0.0754 & 0.0556 & 0.217 & 0.0754 & 0.0556 & 0.215 & 0.0726 & 0.0540 \\
\hline 25 & 0.406 & 0.1431 & 0.1059 & 0.401 & 0.1425 & 0.1054 & 0.398 & 0.1392 & 0.1036 \\
\hline 30 & 0.647 & 0.2376 & 0.1753 & 0.634 & 0.2355 & 0.1734 & 0.628 & 0.2314 & 0.1712 \\
\hline 35 & 0.928 & 0.3581 & 0.2624 & 0.903 & 0.3531 & 0.2581 & 0.892 & 0.3476 & 0.2550 \\
\hline 40 & 1.233 & 0.5018 & 0.3645 & 1.195 & 0.4926 & 0.3568 & 1.177 & 0.4852 & 0.3523 \\
\hline 45 & 1.548 & $0: 6652$ & 0.4785 & 1.499 & 0.6509 & 0.4668 & 1.471 & 0.6408 & 0.4603 \\
\hline 50 & 1.862 & 0.8446 & 0.6012 & 1.803 & 0.8246 & 0.5852 & 1.765 & 0.8111 & 0.5761 \\
\hline 60 & 2.459 & 1.238 & 0.8618 & 2.388 & 1.206 & 0.8376 & 2.327 & 1.183 & 0.8216 \\
\hline 70 & 2.994 & 1.658 & 1.1290 & 2.914 & 1.614 & 1.0976 & 2.840 & 1.581 & 1.0739 \\
\hline 80 & 3.455 & 2.088 & 1.3917 & 3.368 & 2.034 & 1.3538 & 3.297 & 1.991 & 1.3239 \\
\hline 90 & 3.842 & 2.518 & 1.6432 & 3.752 & 2.453 & 1.5996 & 3.692 & 2.403 & 1.5657 \\
\hline 100 & 4.161 & 2.940 & 1.8795 & 4.074 & 2.866 & 1.8314 & 4.022 & 2.809 & 1.7953 \\
\hline 110 & 4.427 & 3.350 & 2.0994 & 4.345 & 3.267 & 2.0480 & 4.295 & 3.206 & 2.0106 \\
\hline 120 & 4.652 & 3.745 & 2.3030 & 4.575 & 3.656 & 2.2492 & 4.523 & 3.590 & 2.2107 \\
\hline 130 & 4.846 & 4.125 & 2.4913 & 4.772 & 4.030 & 2.4359 & 4.720 & 3.960 & 2.3963 \\
\hline 140 & 5.013 & 4.491 & 2.6657 & 4.941 & 4.390 & 2.6089 & 4.895 & 4.316 & 2.5687 \\
\hline 150 & 5.156 & 4.841 & 2.8270 & 5.087 & 4.736 & 2.7693 & 5.050 & 4.659 & 2.7291 \\
\hline 160 & 5.277 & 5.178 & 2.9765 & 5.213 & 5.068 & 2.9182 & 5.182 & 4.989 & 2.8784 \\
\hline 170 & 5.380 & 5.501 & 2.1149 & 5.322 & 5.387 & 3.0565 & 5.293 & 5.307 & 3.0173 \\
\hline 180 & 5.472 & 5.811 & 3.2433 & 5.418 & 5.694 & 3.1850 & 5.387 & 5.612 & 3.1464 \\
\hline 190 & 5.554 & 6.109 & 3.3628 & 5.503 & 5.990 & 3.3048 & 5.469 & 5.906 & 3.2665 \\
\hline 200 & 5.630 & 6.396 & 3.4743 & 5.579 & 6.274 & 3.4167 & 5.546 & 6.188 & 3.3786 \\
\hline 210 & 5.699 & 6.673 & 3.5786 & 5.649 & 6.548 & 3.5213 & 5.618 & 6.460 & 3.4835 \\
\hline 220 & 5.764 & 6.939 & 3.6765 & 5.712 & 6.812 & 3.6195 & 5.683 & 6.723 & 3.5820 \\
\hline 230 & 5.825 & 7.197 & 3.7686 & 5.770 & 7.067 & 3.7117 & 5.741 & 6.977 & 3.6747 \\
\hline 240 & 5.886 & 7.446 & 3.8556 & 5.823 & 7.314 & 3.7986 & 5.791 & 7.223 & 3.7618 \\
\hline 250 & 5.944 & 7.688 & 3.9379 & 5.872 & 7.553 & 3.8806 & 5.837 & 7.460 & 3.8439 \\
\hline 260 & 5.997 & 7.922 & 4.0161 & 5.921 & 7.784 & 3.9581 & 5.883 & 7.690 & 3.9215 \\
\hline 270 & 6.043 & 8.149 & 4.0904 & 5.971 & 8.008 & 4.0317 & 5.928 & 7.913 & 3.9950 \\
\hline 280 & 6.085 & 8.369 & 4.1609 & 6.026 & 8.226 & 4.1020 & 5.969 & 8.129 & 4.0648 \\
\hline 290 & 6.124 & 8.584 & 4.2279 & 6.085 & 8.439 & 4.1693 & 6.004 & 8.339 & 4.1310 \\
\hline 300 & 6.160 & 8.792 & 4.2917 & 6.143 & 8.646 & 4.2342 & 6.044 & 8.543 & 4.1941 \\
\hline 350 & 6.300 & 9.724 & 4.5689 & 6.288 & 9.610 & 4.5225 & 6.270 & 9.464 & 4.4742 \\
\hline 273.15 & 6.057 & 8.219 & 4.1130 & 5.988 & 8.078 & 4.0542 & 5.942 & 7.982 & 4.0173 \\
\hline 298.15 & 6.154 & 8.754 & 4.2801 & 6.133 & 8.608 & 4.2224 & 6.037 & 8.506 & 4.1826 \\
\hline
\end{tabular}

Acta Chem. Scand. 14 (1960) No. 3 
Values of $C_{p}, S_{0}^{\circ}$ and $\left(H^{\circ}-H_{0}^{\circ}\right) / T$ for the three samples at selected temratures are listed in Table 2. No values for the free energy function are given because of the uncertainty about complete ordering of the atoms and holes, just as for the iron-selenides. The enthaply and entropy increments were computed by integration of the heat-capacity equation, obtained by successive approximations on an IBM 650 calculator. The heat-capacity values are considered to have a probable error of $1 \%$ at $10^{\circ} \mathrm{K}$ and $0.1 \%$ above $25^{\circ} \mathrm{K}$. The estimated probable error in the entropy and enthalpy functions is $0.1 \%$ above $100^{\circ} \mathrm{K}$. Some of the data are given to an additional digit because of its significance when the entropies or enthalpies at different temperatures or compositions are compared. The effects of nuclear spin and isotopic mixing are not included in the entropy function.

The non-applicability of the Kopp-Neumann law is immediately evident, since the "molar" heat capacity, and also the entropy, decreases with inreasing selenium content, although the heat capacity and entropy of selenium is higher than for nickel. Within the homogeneity range of the $\mathrm{Ni}_{1-x}$ Se-phase reasonable interpolations could have been made, but even over this narrow range of compositions deviations from additivity are observed. These deviations suggest that interpolations should be made with great caution, and might aid in the resolution of the factors contributing to the heat capacities of phases with NiAs-like structure and cation vacancies.

Acknowledgment. The partial support of the Division of Research, U.S. Atomic Energy Commission, and of Norges Almenvitenskapelige Forskningsråd are gratefully acknowledged.

The authors thank Bolidens Gruvaktiebolag for a generous supply of high-purity selenium and Bruce Justice and Elfreda Chang for assistance in the calorimetric measurements and reduction of the data.

\section{REFERENCES}

1. Alsén, N. Geol. Fören. i Stockholm Förh. 47 (1925) 19.

2. Grønvold, F. and Jacobsen, E. Acta Chem. Scand. 10 (1956) 1440.

3. Grønvold, F. Paper presented at the 2. Nordiske Strukturmote, Oslo 1955.

4. Westrum, E. F. Jr., Chou, C., Machol, R. E. and Grønvold, F. J. Chem. Phys. 28 (1958) 497.

5. Grønvold, F. and Westrum, E. F. Jr. Acta Chem. Scand. 13 (1959) 241.

6. Grønvold, F. Paper presented at the XVI International Congress of IUPAC, Paris 1957.

7. Westrum, E. F. Jr. and Beale, A. F. Jr. To be published.

Received November 14, 1959. 